\title{
OBITUARIES
}

\section{Dr. B. G. Gates}

Dr. Benjamin George Gates, who was the controller of research and development of the Australian Defence Scientific Service in the Department of Supply, died suddenly on December 1, 1964, at the age of sixty. He collapsed at a farewell retirement dinner given by his colleagues at the rooms of the Royal Commonwealth Society in Melbourne. Ho had a distinguished careor in Scientific Research and Development, and for about thirty years was concerned with science in its application to defence.

Gates graduated from the City and Guilds College of the University of London in electrical engineering in 1924, and later was awarded a Ph.D. Between 1924 and 1935 he served with various industrial organizations, including Messrs. Johnson and Phillips, Ltd., London; Metropolitan Vickers, Ltd., Manchester; the British Electric Trunsformer Co., London; and the British Electrical Research Association. In 1935 he joined the Radio Department of the Royal Aircraft Establishment at Farnborough. In this establishment he first became acquainted with some of the scientific problems peculiar to defence, and soon mado his own contribution to their solution.

He was concerned with the provision of reliable radio communication between aircraft and aircraft, and between aircraft and the ground; the comparative ease with which such communication is carried on to-day gives little indication of the magnitude of the problems which had to be overcome. Not the least of these was that of spcech modulation of the radio transmitter in the very high noise-levels encountered in aircraft, and it was in this field that he made one of his most noteworthy contributions. Dr. Gates joined the Radio Department of the Royal Aircraft Establishment as a sciontific officer, and within a decade he was head of that Department.

In 1950 ho joined the Australian Defence Sciontific Service as the controller concerned with the managoment of the Woomera Rocket Range, for which appointment he was specifically, and unequivocally, recommended by the late Sir Henry Tizard. It will be recalled that some three years earlier it had been agroed by the British and Australian Governments that a rocket rango should be set up in Australia for the development of a long-range rocket, which would form the basis of a deterrent weapon system. The range at Woomera was planned originally for this purpose, and a rocket based on the German $V 2$ of the Second World War was conceived under the name Hammer. Within a year, however, as a result of a change in policy of the British Government, this project was cancelled, and it was decided to proceed with the Woomera Range for the development not of a deterrent woapon system but of a series of ground-to-air and air-to-air weapons for direct defence. Dr. Gates was concerned with the planning and building of Woomera for this modified requirement, and he supervised its growth as a general purpose range capable of handling almost any project requiring space and accurate measurement. So in due course the range was readily adaptable to handle the Blue Streak project when, due to another reversal of policy by the British Government, the deterrent wcapon project was revived. Again on cancellation of this project as a weapon, in its turn, the range was found to be readily made suitable for the launching of satellites based on the Blue Streak rocket, under the auspices of the European Launcher Development Organization of which Australia is a member.

Dr. Gates wạs concerned, as 'general manager', not only with the scientific and technical requirements for the range itself, but with all the support which such a facility necessitates. These supporting facilities included the recruitment of some hundreds of graduate scientists and the further training of many of them overseas for periods of up to two years. 'The provision of a town with schools, shops, a hospital and so on was necessary to houso range staff and their dependants, and a supporting air service had to be arranged in co-operation with the Royal Australian Air Force. Clearly, then, the Woomera Rocket Range owes much to the effective management by Dr. Cates in those early days.

In 1955 he was appointed 'controller of research and development' in the Australian Defence Scientific Service and deputy chief scientist (deputy chief executive), and was involved until his death with the build-up and use of rosources capable of providing modern weapons and equipment for the Australian Fighting Services. Partly to train personnel for this purpose, and partly to provide a useful weapon, the British Army's anti-tank weapon Malkara was successfully completed.

In addition to the management of these research and development resources for the Australian Services, and tho supervising of the Australian Dofence Scientific Service as a whole (including the Rocket Range and associated activities) during the absences overseas of the Chief Scientist, Dr. Gates was very closely involved in managing a guided-weapon project, Ikara, for the Royal Australian Navy. The successful completion of this sophisticated system, which accurately delivers a selfhoming torpedo to a desired location at sea, is due in large measure to Gates's conscientious supervision. Gates had a wide knowledge of those branches of science concerned with defence and, in the field of electrical engineering and electronics, this knowledge was encyclopaodic. He was a most pleasant colleague with whom to work and was unruffled in a crisis; his loss will be deeply felt. He leaves a wife, a daughter and a son.

W. A. S. Butement

\section{S. Franklin, C.B.E.}

Charles Samuel Franklin, one of the greatest pioneers of radio telecommunications, died on December 10,1964 , at the age of eighty-five. He will always be honoured for the prominent part he played in the small band of engineers associated with Guglielmo Marconi in the development of wireless-now radio-communications and associated valve techniques, during the first half of this century.

Franklin was born in 1879 and received his engineering and scientific training at the Finsbury Technical College under Prof. Sylvanus Thompson. After gaining some experience in electrical work, first at Manchester and afterwards with the Norwich Electricity Co., he joined the Wireloss Telegraph and Signal Co. in 1899. This organization later became Marconi's Wireless Telegraph Co., with which Franklin remained associated until his retirement in 1939.

After a period in South Africa, where he helped to introdueo wireless communication as a military aid during the Boer War, he sailed with Marconi across the Atlantic in 1902 to demonstrate tho reception of wireless messages up to a range of some 1,550 miles from the Poldhu transmitting station in Cornwall. This was followed by a long personal association between Franklin and Marconi, during which were laid the foundations of modern worldwide radio communications.

Beginning with specially designed spark transmitters, Franklin was quick to appreciate the possibilities of the thermionic valve as a generator of radio frequency 